\title{
RECORDS OF THE OLDSQUAW IN SOUTHERN MANITOBA
}

DONALD A. SEXTON and K. MICHAEL COLLINS, Department of Zoology, University of Manitoba, Winnipeg, Manitoba

On the afternoon of November 10 , 1976, we observed a female Oldsquaw at Victoria Beach, Lake Winnipeg (Fig. 1). It was swimming near the shore with a female Common Goldeneye. We identified the Oldsquaw immediately as observation conditions were excellent.

The birds were observed for several minutes until the goldeneye flushed. The Oldsquaw followed and both birds flew along the shore for several hundred metres before landing. We approached the birds again and viewed them for about one more minute. Both birds flushed once again and flew out of sight toward Elk Island (1 - numbered locations in text correspond to those in Fig. 1).

W. E. Godfrey did not record the Oldsquaw in southern Manitoba (south of $54^{\circ} \mathrm{N}$. latitude), but we have accumulated several records of the Oldsquaw in this region. ${ }^{4}$ The earliest available record is a male shot by $H$. W. O. Boger at Whitehead Lake on October $19,1899 .{ }^{6}$ A. G. Lawrence, in a later summary of Oldsquaw records in southern Manitoba, reports this specimen being from Whitewater Lake (2). ${ }^{9}$ Another specimen was shot on Lake Winnipegosis "prior to 1921 " by J. P. Rosser (3). It was deposited in the Manitoba Agricultural College Museum. ${ }^{9}$ Lawrence documented a report by C. G. Harrold of a male Oldsquaw in breeding plumage close to the shore of Lake Winnipeg near Gimli on May 2, 1921 (4). ${ }^{6} 9$ Another male Oldsquaw was observed in a flock of scaup by C. L. Borley on the Red River near St. Boniface Hospital on October 27, 1925 (5). ${ }^{8}$ At Matlock, in October, 1925, a male Oldsquaw was shot by Mr. Collede and reported by E. W. Darbey (6). ${ }^{9}$ Norris-Elye of the Manitoba Museum observed a male Oldsquaw on September 18,
1926, while travelling between Harbor and the mouth of the 1 River on Lake Winnipeg (7). ${ }^{10}$ another male was shot on October 1928, at Oak Point Lake near Lib by J. P. Phillip (8). ${ }^{10}$ On Novembe 1930, an immature male was sho G. E. Leslie at Clandeboye Bay Lake Manitoba (9). ${ }^{11}$ Also on L Manitoba, a male was shot "the week of September", 1932 near L dar (10). ${ }^{12}$ P. Gramma, a fishermar Lake Winnipeg, found a male $\mathrm{O}$ quaw frozen on Elk Island during winter of 1934 (11). ${ }^{13}$ Waller descr a specimen in his collection taker J. Reader at Reader Lake near The on September 26, 1947 (12). ${ }^{16}$ Oldsquaw was reported at Delta May 7, 1956, in the Delta Water Research Station Spring Migra Records (13). R. W. Sutton obsel an Oldsquaw in the Whites Provincial Park on May 11, 1957 (1 An immature female Oldsq (Manitoba Museum of Man Nature No. 2339) was shot on Octs 26, 1957, at Netley by A. Sagness Another female Oldsquaw was sh Delta by G. S. Hochbaum (pers. $c$ m.) in the fall of 1961 (16). H. C. shot a male Oldsquaw (MMMN 2989) on October 23, 1970, at Whiteshell Lake (17). During winter of 1971-72, a male Oldsc attempted to winter in open $v$ below the dam on the Rat River St. Malo (18). It was seen ther December, 1971, by personnel oth Manitoba Department of Renen, Resources and Transportation vices. In January, 1972, presum? this same bird was found on a ne $b$ road, killed by a car. It was recov e by $M$. Comeau and deposited it Manitoba Museum of Man Nature (No. 3215). According to [ J. Batt, Delta Waterfowl Research to tion, two juvenile male Oldsı aı 


\section{The Pas}
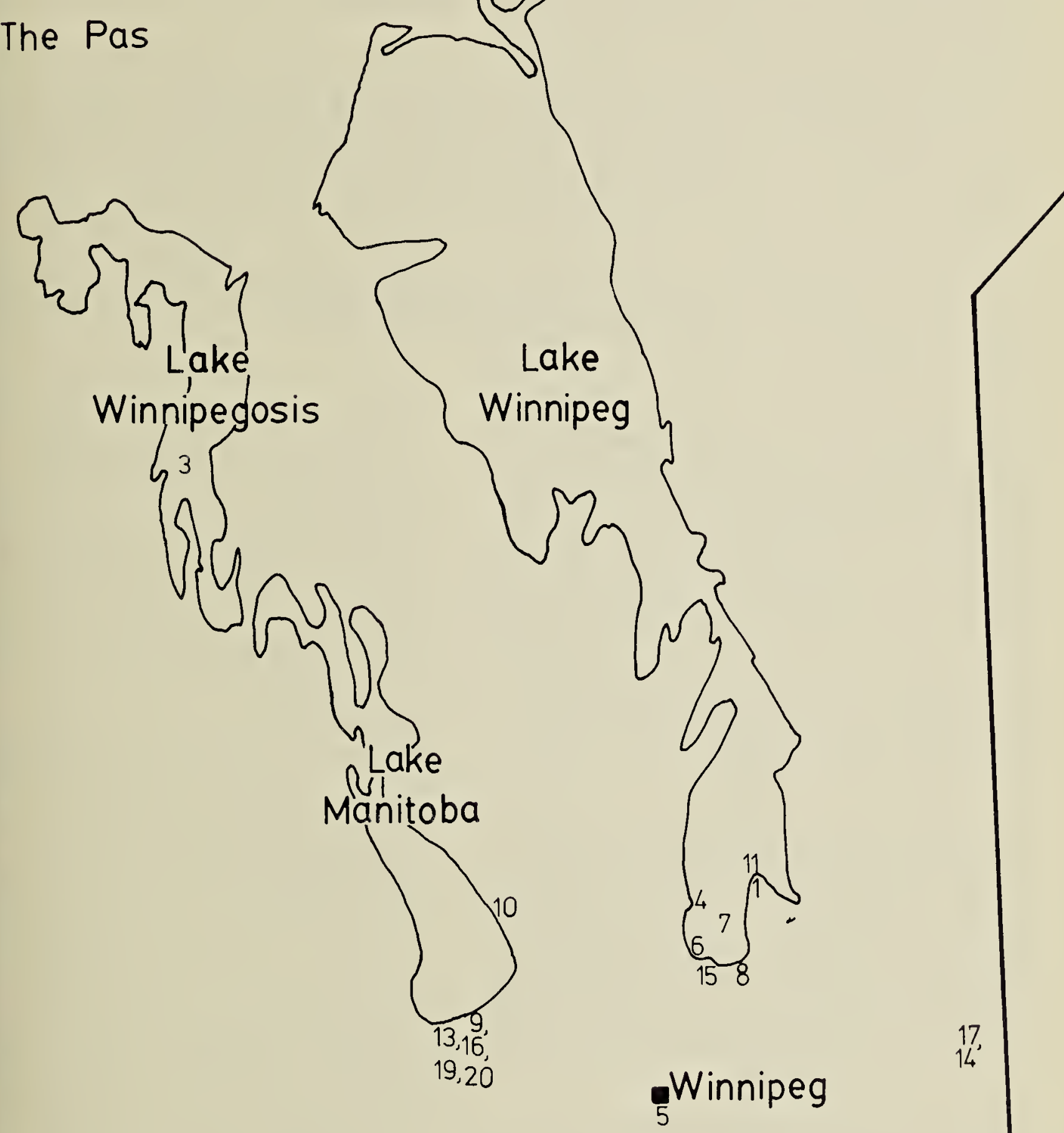

18

2

1. Locations of Oldsquaw records in southern Manitoba.

e recovered in a hunter bagck near Delta between October $8,1975(19,20)$.

he Oldsquaw is a tundra nester a circumpolar distribution. ${ }^{23} 4$
They are common nesters along Hudson Bay in northern Manitoba. ${ }^{1} 2345$ In North America, this species winters along both coasts and on the Great Lakes. ${ }^{1234}$ Some birds have been 
recorded wintering on the Mississippi River and the Gulf of Mexico. ${ }^{2}$

Portions of the Churchill population migrate through the Great Lakes, with some birds wintering on Lakes Ontario and Michigan. ${ }^{12}$ Other individuals migrate to the Atlantic coast. $^{2}$ R. M. Alison suggests that most of the Oldsquaw wintering on Lake Ontario come from the Arctic via James Bay (pers. comm.). It is possible that some Oldsquaw migrate each year through southern Manitoba. That this species usually inhabits broad expanses of open water rather than marshes may account for the paucity of sightings. Further, much of the shoreline of Lakes Winnipeg, Manitoba, and Winnipegosis is inaccessible and observers seldom venture out on these lakes in search of birds. Fourteen of our records are from these large lakes. Since 17 are from fall or winter, it might appear that Oldsquaw migrate through southern Manitoba only in the fall. It is more likely that the preponderance of fall records reflects hunter reports of unusual birds shot.

One spring sighting was made offshore on Lake Winnipeg. ${ }^{6}$ This indicates that Oldsquaw may be present during spring migration, but normally beyond the range of most observers. The spring record from the Whiteshell Provincial Park also occurred in an area not frequented by many bird watchers.

R. M. Alison has received spring records of Oldsquaw up to 400 miles inland from Churchill (pers. comm.). These records were mainly from rivers draining into Hudson Bay, particularly the lower Nelson River. Oldsquaw occurred in these areas prior to the spring break-up of tundra ponds along the Arctic coast. Alison suggested that spring migration of Oldsquaw occurs over a broad front, proceeding overland from the Great Lakes (pers. comm.). Palmer states that some Oldsquaw migrate northwest from Lake Superior in the spring. ${ }^{15}$ Spring records from Whiteshell Provincial Park and Lake Winnipeg lend credence to this hypothesis. Therefore, we feel the is plausible that a small number Oldsquaw migrate in both spring fall each year through south Manitoba.

We wish to thank the follow who supplied information for note: Bruce D. J. Batt, Maur Comeau and George S. Hochba Herbert W. R. Copland provi valuable assistance in collect records. We benefitted from cussions with Robert M. Alison. thank Spencer G. Sealy for reac the manuscript.

${ }^{7}$ ALISON, R. M. 1975. Breeding biology behavior of the Oldsquaw (Clan hyemalis L.). Ornithological Mi graphs No. 18.

${ }^{2}$ BELLROSE, F. C. 1976. Ducks, geese, swans of North America. Stack Books, Harrisburg, Va. 544 pp.

${ }^{3}$ BENT, A. C. 1938. Life histories of $N$ American wild fowl. Part 2. U.S. Mus. Bull. 130.

${ }^{4}$ GODFREY, W. E. 1966. The bird Canada. Nat. Mus. Canada Bull.

5JEHL, J. R., and B. A. SMITH. 1970. Bir the Churchill Region, Man. Mani Museum of Man and Nature Sp Publication No. 1

${ }^{6}$ LAWRENCE, A. G. 1921. Chickadee N No. 6. Winnipeg Free Press. M 1921

'LAWRENCE, A. G. 1921. Chickadee N No. 7. Winnipeg Free Press. 12, 1921.

${ }^{8}$ LAWRENCE, A. G. 1925. Chickadee N No. 240. Winnipeg Free Press. Oc 29, 1925.

${ }^{9}$ LAWRENCE, A. G. 1925. Chickadee N No. 245. Winnipeg Free Press. 3, 1925.

${ }^{10}$ LAWRENCE, A. G. 1928. Chickadee 1 e No. 403. Winnipeg Free Press. 13, 1928.

${ }^{11}$ LAWRENCE, A. G. 1930. Chickadee i e No. 505. Winnipeg Free Press. 28, 1930.

${ }^{12}$ LAWRENCE, A. G. 1932. Chickadee i te No. 604. Winnipeg Free Press. 'C 21, 1932.

${ }^{13}$ LAWRENCE, A. G. 1934. Chickadee I te No. 675. Winnipeg Free Press. N 2, 1934 . 
PSSOP, H. 1957. Chickadee Notes. No. 123. Winnipeg Free Press. May 24, 1957.

LMER, R. S. (ed.) 1976. Handbook of North American birds. Volume 3.
Waterfowl. Yale University Press, New Haven. 560 pp.

${ }^{16}$ WALLER, S. 1967 . Some interesting bird records from The Pas, Manitoba. Blue Jay 25: 120 .

\section{LAND RECORDS OF THE ROCK ARMIGAN IN MANITOBA}

NALD A. LARCHE, Manitoba Department of Renewable Resources and isportation Services, Winnipeg, Manitoba, R3H OW9 and

NCER G. SEALY, Department of Zoology, University of Manitoba, Winnipeg, hitoba, R3T 2 N2.

he Rock Ptarmigan was conred by Taverner and Sutton to be regularly common, winter visitor Churchill, Manitoba. ${ }^{10}$ More ntly, Lumsden summarized the rds of its occurrence in Manitoba Ontario and found that it moves hward occasionally in winter $\mathrm{g}$ or within a few kilometres of Hudson Bay and James Bay ts. ${ }^{4}$ Jehl and Smith also noted that $k$ Ptarmigans winter in varying bers in the Churchill area, with major influx occurring in late fall. ${ }^{3}$ observed the remains of Rock migans killed by predators up to $\mathrm{km}$ inland.

dditional records presented here cate that Rock Ptarmigans oconally move further inland in itoba than Lumsden's records v. During such years, it may be abundant but inconspicuous by sociation with the more common familiar Willow Ptarmigan.

n December 10, 1975, one of us .L.) collected three Rock and two ow ptarmigans from the same eral area, about $3 \mathrm{~km}$ west of $\mathrm{m}$ and about $280 \mathrm{~km}$ from the son Bay coast. One male Rock migan (UMZM 450) weighed 513 pe other male (UMZM 451) was aged. The female Rock Ptarmigan IZM 452) weighed $484 \mathrm{~g}$. One ow Ptarmigan (UMZM 453), a weighing $501 \mathrm{~g}$, was preserved; the crop of the damaged second vidual of unknown sex, was saved.
A third Rock Ptarmigan, with a black eye stripe, was seen by Larche on the same date, about $300 \mathrm{~m}$ from where the birds were collected. All of the preserved ptarmigans were adults, using the criteria of outer primary pigmentation to age them. ${ }^{1}{ }^{12}$

Much earlier, on December 15, 1928, J. T. Martin collected a Rock Ptarmigan at Gillam (Nat. Mus. Can. 50752). ${ }^{2}$ Even further inland, Mowat and Lawrie reported the species near Brochet, Manitoba, on December 11 and 14, $1947 .{ }^{6}$ In the Lake Athabasca region of northwestern Saskatchewan, Nero presented evidence for occasional winter movements of Rock Ptarmigans there. ${ }^{7}$ Nero did not record them in northeastern Saskatchewan. ${ }^{8}$

Both Willow Ptarmigan crops contained willow (Salix spp.) buds and twigs. Two of the Rock Ptarmigan crops contained swamp birch (Betula glandulifera) buds and catkins. The third Rock Ptarmigan crop contained willow buds and twigs, swamp birch catkins, sedge (Carex spp.) and three unknown buds. Such differences in the food habits of Willow and Rock ptarmigan, taken from the same locality near Gillam, are comparable to those found in these species in winter in Alaska. ${ }^{511}$

Although the two ptarmigan species can usually be distinguished in the field in winter by the presence of a black eye stripe in both sexes of 